\title{
HIGHER ORDER THINKING BERBASIS PEMECAHAN MASALAH UNTUK MENINGKATKAN HASIL BELAJAR BERORIENTASI PEMBENTUKAN KARAKTER SISWA
}

\author{
Tri Widodo dan Sri Kadarwati \\ FMIPA Universitas Negeri Semarang \\ email: triwidodo@yahoo.com
}

\begin{abstract}
Abstrak: Penelitian tindakan ini ditujukan untuk meningkatkan aktivitas dan hasil belajar siswa dengan berorientasi pembentukan karakter. Pembelajaran menggunakan higher order thinking berbasis pemecahan masalah. Subjek penelitian adalah siswa kelas XI-3 program IPA. Temuan penelitian menunjukkan bahwa hasil belajar siswa meningkat menjadi 73,84 (melebihi target). Siswa yang telah menguasai materi ada sebanyak 96,87\%. Skor aktivitas adalah 83,81 (melebihi target). Karakter dan respon siswa terhadap pembelajaran termasuk pada kategori baik.
\end{abstract}

Kata Kunci: higher order thinking, hasil belajar, aktivitas belajar dan karakter

\section{PROBLEM-SOLVING-BASED HIGHER ORDER THINKING TO IMPROVE LEARNING ACHIEVEMENT THROUGH STUDENTS' CHARACTER BUILDING ORIENTATION}

\begin{abstract}
This action research study was aimed to improve the students' learning activities and achievement through character building orientation. The teaching used the higher order thinking and problem-based instruction strategy. The subjects were the XI-3 students of the Science program. The findings showed that the students' achievement was 73.84 (higher than the target). The students who had mastered the lesson was $96.87 \%$. The activity score was 83.81 (higher than the target). The students' character and response to the teaching process belonged to the good category.
\end{abstract}

Keywords: HOT, PBI, student achievement, student character

\section{PENDAHULUAN}

Penelitian ini diawali oleh rasa prihatin terhadap sikap siswa SMA yang takut menghadapi Ujian Nasional. Ujian Nasional telah dilaksanakan selama bertahun-tahun, bahkan jika ditelusur ke masa lampau, ujian itu telah diselenggarakan selama puluhan tahun dengan nama EBTA, EBTANAS atau Ujian Negara, tetapi kenyataannya siswa kurang dipersiapkan dengan baik sehingga takut menghadapi Ujian Nasional. Mereka khawatir kalau-kalau tidak lulus Ujian Nasional. Hal itu terjadi pada hampir semua sekolah termasuk SMA N 1 Ungaran yang telah menyandang status sebagai Rintisan Sekolah Bertaraf Internasional (RSBI).
SMAN 1 Ungaran termasuk sekolah unggulan di Kabupaten Semarang. Sekolah ini memiliki visi: Unggul dalam Prestasi dan Luhur dalam Budaya, namun demikian prestasi akademik yang diraih "baru" di tingkat kabupaten dan belum ke tingkat Nasional. Input sekolah ini tergolong baik terutama di tingkat kabupaten Semarang, setiap tahun calon yang mendaftar berlimpah sehingga sekolah dapat memilih siswa yang berkualitas, namun dalam prestasi akademik seperti lomba olimpiade tingkat provinsi Jawa Tengah, tingkat Nasional atau Internasional, siswa-siswa sekolah ini belum menunjukkan prestasinya secara maksimal.

Meskipun masukan siswa tergolong baik, tetapi proses pembelajarannya, khususnya mata pelajaran Kimia, masih relatif konvansional. 
Guru berorientasi mengejar target pencapaian materi, tetapi belum mengembangkan kompetensi yang dimiliki siswa secara maksimal seperti tuntutan kurikulum RSBI. Di dalam kelas guru menjelaskan materi ajar, memberi contoh dan bukan contoh, latihan soal dan kemudian memberi pekerjaan rumah (PR). Proses pembelajaran yang seharusnya dilaksanakan dalam bahasa Inggris juga tidak sepenuhnya dilaksanakan karena kemampuan guru mengajar dalam bahasa Inggris masih terbatas.

Demikian juga kebermaknaan pelajaran yang terkait dengan kehidupan sehari-hari masih belum diintegrasikan dalam proses belajar mengajar secara maksimal karena guru mengejar target materi ajar. Dalam pembelajaran di laboratorium, siswa melakukan praktikum untuk membuktikan kebenaran teori, tetapi belum diarahkan "menemukan" teori sehingga seolaholah praktikum adalah menguji kebenaran teori yang diajarkan di kelas dan siswa belum mengkonstruksi konsep atau teori. Sebagai akibatnya siswa juga kurang dipersiapkan untuk menghadapai persoalan yang lebih kompleks dan lebih sulit, termasuk memecahkan soal-soal setingkat Lomba Olimpiade atau Soal Ujian Nasional.

Pengembangan karakter siswa unggul khususnya karakter ilmuwan seperti hati-hati, teliti, berani menghadapi masalah, jujur, objektif, bertanggung jawab terhadap tugas, tekun, toleransi, dan karakter lain yang merupakan karakter unggulan RSBI belum sepenuhnya digarap, tetapi berlangsung seperti apa adanya. Dari segi peraturan sekolah secara tegas dinyatakan oleh SMA N 1 Ungaran bahwa siswa harus berkarakter baik, bahkan harus unggul dalam prestasi maupun budaya seperti tertulis pada visi sekolah tersebut. Model pembelajaran di sekolah ini masih konvensional, kurikulumnya juga KTSP, belum seperti tuntutan RSBI yang mengacu pada salah satu Negara OECD atau negara maju. Pembelajaran masih seperti sekolah bukan RSBI, perbedaaannya hanyalah pengantar bahasa Inggris yang tidak sepenuhnya dilaksanakan. Dengan demimian, sebutan Sekolah Bertaraf Internasional belum cocok atau tidak sesuai dengan tuntutan RSBI yang harus menerapkan model pembelajaran yang bertaraf internasional pula.

Salah satu pendekatan pembelajaran untuk RSBI menurut Haryanto (2011) harus menggunakan Higher Order Thinking (HOT), baik untuk PBM di kelas maupun dalam evaluasi pembelajaran. Haryanto (2011) juga menyatakan bahwa selama ini ada "salah kaprah", yakni RSBI ditandai oleh pembelajaran menggunakan bahasa Inggris saja, padahal bahasa itu merupakan suatu "keharusan", syarat yang semestinya sudah ada pada RSBI sehingga bahasa Inggris bukan satu-satunya ciri RSBI, tetapi prestasi dan kualitas pembelajaran internasional sebagai ciri unggul RSBI yang harus dikedepankan.

Newman and Wehlage (2011) menyatakan bahwa "HOT requires students to manipulate informations and ideas in ways that transform their meaning and implications, such as when students combine facts and ideas in order to synthesize, generalize, explain, hypothize, or arrive at some conclusion or interpretation. Dengan HOT siswa akan belajar lebih mendalam, knowledge is thick, siswa akan memahami konsep lebih baik. Hal itu sesuai dengan karakter yang substantif untuk suatu pelajaran ketika siswa mampu mendemonstrasikan pemahamannya secara baik dan mendalam. Dengan HOT siswa dapat membedakan ide atau gagasan secara jelas, berargumen dengan baik, mampu memecahkan masalah, mampu mengkonstruksi penjelasan, mampu berhipotesis dan memahami hal-hal kompleks menjadi lebih jelas. Thomas dan Thorne (2011) menyatakan bahwa bahwa HOT dapat dipelajari, HOT dapat diajarkan pada murid, dengan HOT keterampilan dan karakter siswa dapat ditingkatkan. Selanjutnya dikatakan bahwa ada perbedaan hasil pembelajaran yang cenderung hapalan dan pembelajaran HOT yang menggunakan pemikiran tingkat tinggi.

Berpikir berarti menggunakan kemampuan analitis, kreatif, perlu praktek, dan intelegensi semacam itu diperlukan dalam kehidupan sehari-hari. Kemampuan berpikir tingkat tinggi semacam meta-kognitif merupakan bagian dari kemampuan berpikir tingkat tinggi (Higher 
Order Thinking). Mc Loughlin and Luca (2011) menyatakan bahwa HOT means the capacity to go beyond the information given, to adopt a critical stance, to evaluate, to have metacognitive awarness and problem solving capacities.

Dikatakan pula bahwa dengan HOT siswa menjadi pemikir yang mandiri, argumen yang dikemukakan siswa dapat merupakan petunjuk kualitas kemampuan siswa. Penggunaan HOT sebagai salah satu pendekatan pembelajaran menghasilkan aktivitas belajar yang produktif khususnya dalam interaksi socio-cognitive, misalnya dalam hal: (1) memberi dan menerima bantuan; (2) mengubah dan melengkapi sumber informasi; (3) mengelaborasi dan menjelaskan konsep; (4) berbagi pengetahuan dengan teman; (5) saling memberi dan menerima balikan; (6) menyelesaikan tugas dalam bentuk kolaboratif, dan (7) berkontribusi dalam menghadapi tantangan. HOT ini akan lebih bagus jika dikaitkan dengan Problem Solving Instruction atau Problem-Based Instruction (PBI) karena muara dari pola berpikir tingkat tinggi adalah mampu menyelesaikan masalah. Dengan pendekatan HOT siswa dapat diajak untuk aktif berpikir sehingga mereka juga aktif belajar, khususnya dalam pemecahan masalah.

Kemampuan pemecahan masalah merupakan kompetensi strategik supaya siswa mampu memahami, memilih pendekatan dan strategi pemecahan masalah sehingga mampu menyelesaikan persoalan atau masalah. Dalam pemecahan masalah siswa dapat menunjukkan kemampuan memahami masalah dengan baik, mengorganisasi data yang relevan, menyajikan masalah secara jelas, memilih pendekatan atau strategi pemecahan dan mampu menerapkan model pemecahan yang efektif. Wena (2011) menyatakan bahwa PBI memiliki kelebihan antara lain (1) PBI merupakan teknik yang baik untuk memahami pelajaran secara baik; (2) PBI menantang siswa serta memberi peluang pemecahan masalah; (3) PBI dapat meningkatkan aktivitas belajar siswa; (4) PBI dapat membantu siswa mentransfer pengetahuan untuk pemecahan masalah dalam kehidupan nyata; 5) PBI memberi peluang siswa untuk mengembangkan kemampuan berpikir tingkat tinggi (HOT) bah- kan berpikir kritis; dan (6) PBI merangsang minat siswa untuk selalu belajar.

Widodo, Sunaryati dan Rochmadi (2010) menemukan fakta bahwa dengan pendekatan HOT-PBI (Higher Order Thinking and Problem-Based Instruction) yang dilaksanakan di SMA N 3 Semarang, aktivitas belajar siswa mampu mencapai skor 80 (rentang 0 -100) dan Kriteria Ketuntasan Minimal hasil belajar sebesar 75 mampu dicapai oleh $85 \%$ siswa kelas XI IPA-7. Hasil belajar tersebut stabil pada siklus 2, 3 dan 4, dan juga pada ulangan umum semester gasal. Dalam melatih kemampuan siswa berpikir tingkat tinggi, SMA N 3 Semarang menganggap perlu adanya kelas khusus yang disebut kelas olimpiade untuk membina dan menyiapkan pemikir-pemikir muda dalam menghadapi tantangan soal-soal olimpiade. HOT terkait erat dengan kemampuan pemecahan masalah, namun kemampuan pemecahan masalah siswa Indonesia tergolong rendah.

Dalam hal pemecahan masalah, Sujak (2005) dan Surya-Dharma (2009) menyatakan bahwa para pendidik prihatin terhadap kemampuan pemecahan masalah siswa-siswa Indonesia. Dari 100 siswa yang dikirim mengikuti lomba tingkat internasional yang diselenggarakan PISA (Program for International Students Assessment), 73 di antara 100 siswa yang dikirim berada di bawah level yang paling bawah (level 1). Hal itu menunjukkan bahwa siswasiswa Indonesia belum mampu memecahkan masalah dengan baik, atau kemampuan pemecahan masalahnya sangat rendah. Dalam hal pemecahan masalah, Ruseffendi (1991: 291) menyatakan bahwa pemecahan masalah bukan hanya diperlukan dalam pelajaran Matematika tetapi pada semua pelajaran (ilmu) terutama yang terkait dengan pemecahan masalah dalam kehidupan sehari-hari.

Suyitno (2006:25) yang mengutip pendapat Wiederhold, menyatakan bahwa model pemecahan masalah dipandang sebagai model pembelajaran yang mampu meningkatkan kemampuan siswa dalam berpikir tinggi (HOT). Model pemecahan masalah dengan pola berpikir tinggi akan membawa siswa pada pengalaman siswa menggunakan pengetahuan serta 
keterampilan secara maksimal untuk dapat diterapkan dalam hal pemecahan masalah yang tidak rutin, penemuan pola pemecahan, perampatan hasil serta kemampuan komunikasi yang baik, sehingga kebermaknaan belajar akan lebih terasa.

Beberapa penelitian tentang Problem based maupun Problem Solving Instruction menunjukkan bahwa hasil belajar dengan problem based maupun problem solving lebih baik sari pada metode ekspositori, demikian pula dalam hal aktivitas belajar para siswa (Pujiadi, 2008; Nurjanah, 2006; dan Ratnasari, 2005). Dinyatakan Ratnasari (2005) bahwa kemampuan penalaran siswa yang diberi pembelajaran dengan Problem-Based Instruction lebih baik dibandingkan dengan pembelajaran konvensional.

Dalam kehidupan sehari-hari banyak masalah yang tidak dapat diselesaikan sendirian, tetapi dengan kerjasama masalah sulit dapat diselesaikan bersama-sama. Demikian pula masalah yang dihadapi siswa tidak seluruhnya dapat dikerjakan sendirian, dalam hal ini siswa perlu kerjasama dalam kelompok. Dalam kerjasama tersebut siswa dapat berbagi (sharing), dapat memberi maupun menerima ide teman satu kelompok, dapat berinteraksi saling bertanya dan atau menjawab, dapat melatih demokrasi dan sikap lain. Hal itu memberi kesempatan untuk menumbuhkan karakter-karakter siswa yang baik.

Karakter yang dapat dikembangkan dalam penelitian ini adalah karakter yang berdekatan dengan karakter ilmuwan seperti hati-hati, teliti, obyketif, jujur, kerjasama, tekun, bertanggungjawab dan disiplin, sebagai bentuk nurturent effect pembelajaran dengan pendekatan HOT-PBI. Kadang dijumpai sifat kurang hatihati dan kurang teliti dalam menjawab persoalan, dalam hitungan matematik misalnya, demikian pula kadang siswa tidak teliti dalam mengerjakan percobaan. Sebagai contoh adalah adanya miskonsepsi siswa pada pemahaman bentuk atom atau bentuk geometri molekul, meskipun guru sudah menjelaskan bentuk atom adalah bulat, tetapi karena guru menggambar ikatan antar atom dalam bidang dengan garisgaris ikatan, siswa membuat "model molekul" yang salah. Model atom dibuat kotak-kotak, ikatan tidak menyudut seperti seharusnya (misalnya sekitar $104^{\circ}$ ) tetapi menyudut siku-siku $\left(90^{\circ}\right)$ seperti gambaran guru pada papan tulis yang mendatar.

Pembentukan karakter semakin penting ditekankan karena bangsa Indonesia menghadapi banyak permasalahan yang membahayakan kehidupan berbangsa dan bernegara (Suparman, 2011). Dalam pengembangan karakter, Selleck dalam Mutohir (2011) menganjurkan tiga langkah guru, yaitu model: memberi contoh, mengajar: memberi bimbingan dan encouregement: memberi motivasi. Mutohir (2011) juga menyatakan bahwa performance character seperti ketekunan, kegigihan, etika, kerja keras, disiplin dan sikap positip dapat diajarkan kepada murid.

Di SMA N 1 Ungaran khususnya kekas XI IPA-3 hasil belajar belum memuaskan, banyak siswa yang tidak tuntas. Siswa cenderung sulit memecahkan soal hitungan. Siswa cenderung bekerja mandiri karena mereka merasa sebagai siswa unggul, persaingan antar siswa tinggi. Dalam hal memecahkan soal sulit diperlukan kerjasama, ketekunan dan kegigihan, oleh karena itu pembelajaran dengan membentuk kerjasama juga diperlukan.

Berdasarkan paparan tersebut, tujuan penelitian adalah meningkatkan hasil belajar (rerata di atas 70 dan yang tuntas minimal $85 \%$ ), dan aktivitas belajar yang berorientasi pada peningkatan karakter siswa kelas XI-IPA 3 SMA Ungaran sampai batas maksimum. Pengertian istilah maksimum adalah hasil tertinggi yang memungkinkan dicapai oleh siswa. Untuk hasil belajar Kimia, Kriteria Ketuntasan Minimal (KKM) di RSBI di seluruh Indonesia adalah 75, tetapi KKM ini kurang riel karena satu sekolah (RSBI) dengan sekolah (RSBI) lain kondisi sekolah berbeda, siswa, sarana prasarana, guru dan pengelolaannya tidak sama. Dalam hal ini KKM Kimia di SMA Ungaran jika sudah mencapai 70 (nilai asli) per siswa adalah sudah maksimum; sementara jika siswa $75 \%$ aktif belajar hal itu sudah maksimum. Untuk aspek karakter sebagai bentuk ikutan pembelajaran HOT-PBI yang diinginkan adalah sifat teliti, hati-hati, obyektif, jujur, tekun, disiplin dan 
sikap bertanggung jawab ditargetkan minimal berkategori baik.

\section{METODE}

Metode penelitian yang dipilih adalah metode penelitian dengan pendekatan penelitian tindakan kelas. Pemilihan pendekatan ini berdasarkan alasan yang akan diteliti bukan semata produk hasil (hasil belajar), tetapi juga proses (aktivitas) serta karakter yang tidak diukur sesaat, tetapi perlu waktu (pengembangan disiplin, jujur, teliti, hati-hati dan tanggung jawab butuh waktu). Setting penelitian ini adalah kelas XI IPA-3. Kelas ini terdiri dari 32 siswa dengan 21 siswa putri dan 11 siswa putra. Kondisi sarana dan prasarana yang baik, laboratorium Kimia, Fisika dan Biologi termasuk lengkap, guru Kimia ada tiga orang seluruhnya termasuk senior dengan pengalaman kerja lebih dari 20 tahun dengan golongan Iva, dan sudah memperoleh sertifikat pendidik. Meskipun demimkian guru Kimia yang "berani" mengajar dengan pengantar bahasa Inggris hanya satu orang.

Penelitian dilakukan dengan persiapan dimulai pada bulan Agustus, dimulai dengan diskusi-refleksi tentang pelaksanaan pembelajaran berbahasa Inggris di SMAN 1 Ungaran, kendala pelaksanaan, metode pembelajaran, hasil belajar siswa, aktivitas belajar di kelas dan di laboratorium, evaluasi belajarnya serta karakter siswa jika mendapat tantangan tugas berat. Pembelajaran Kimia belum menggunakan bahasa Inggris, siswa belum mampu menangkap pembelajaran berbahasa Inggris dengan baik, kegiatan praktik dilaksanakan sekali-sekali, evaluasi cenderung dengan soal-soal standar yang belum menggambarkan Sekolah Bertaraf Internasional.

Dalam rangka membiasakan pola pikir tingkat tinggi dan mengembangkan karakter berani menghadapi tantangan maka dipilih metode pembelajaran Hinger Order Thingking Problem Based Instruction (HOT PBI). Pembelajaran ini direncanakan melibatkan dua siklus, dua pokok bahasan yang meliputi Termokimia (siklus 1), Laju Reaksi, termasuk Orde Reaksi dan Teori Tumbukan (siklus 2), serta pokok bahasan Kesetimbangan Kimia (rencana cadangan siklus
3), diakhiri dengan Ulangan Umum. Fokus penelitian adalah aktivitas belajar, hasil belajar kognitif, respons siswa dan karakter siswa. Aspek kognitif diukur dengan tes tiga kali, aktivitas belajar di kelas dan di laboratorium diukur dengan lembar pengamatan, empat kali, dan karakter diukur dengan lembar pengamatan empat kali, respons siswa diukur dengan angket dilakukan pada akhir penelitian.

Prosedur penelitian mengikuti langkahlangkah penelitian tindakan kelas, dimulai dari observasi awal, penetapan masalah, penetapan pemecahan masalah, persiapan penelitian khususnya membuat perencanaan untuk semua kegiatan, penyiapan instrumen, pelaksanaan tindakan, observasi, refleksi dan analisis data. Prosedur PTK ini pada prinsipnya menggunakan model Kemmis dan Mc Taggart.

DalamKegiatan Belajar mengajar (KBM) guru cenderung mengejar tercapainya materi ajar, kurang melibatkan siswa secara optimal, siswa cenderung belajar jika ada ulangan, interaksi siswa-siswa maupun guru-siswa kurang. Dengan modal observasi awal tersebut maka tim peneliti memutuskan bahwa untuk mengaktifkan siswa belajar lebih giat di kelas XI IPA 3 dapat diterapkan pembelajaran Kimia dengan tantangan lebih berat dari biasanya, yaitu dengan Higher Order Thinking-Problem-based Instruction (HOT-PBI). Pemilihan strategi pembelajaran dengan HOT-PBI dimaksudkan supaya siswa mau belajar lebih giat dengan tantangan pemecahan soal-soal yang memerlukan pemikiran tingkat tinggi.

Fokus penelitian adalah hasil belajar dalam aspek kognitif yang diukur dengan tes, psikomotor yang diukur dalam bentuk aktivitas belajar di dalam kelas maupun praktikum di laboratorium, karakter yang diukur dari lembar pengamatan dan afeksi tentang pelaksanaan tugas, serta respons siswa terhadap penerapan model pembelajaran dengan pendekatan HOTPBI. Instrumen yang digunakan untuk mengambil data adalah tes, lembar pengamatan dan angket. Rencana Pelaksanaan Pembelajaran (RPP), Instrumen Penelitian didiskusikan oleh tim sebelum digunakan dalam pelaksanaan. Usaha validasi instrumen dilaksanakan dengan 
memperhatikan Isi Kurikulum, konstruk konsep yang diukur, dan kesepakatan tim peneliti. Target atau indikator keberhasilan yang ditetapkan, rerata kelas mencapai nilai minimal 70 , dari seluruh siswa di kelas XI IPA 85\% siswa diharapkan tuntas, aktivitas belajar siswa secara rerata minimal 70 (baik), demikian juga karakter siswa tergolong baik (skor minimal 70).

Prosedur penelitian mengikuti model PTK dengan siklus-siklus Perencanaan, Tindakan, Observasi dan Refleksi (P-T-O-R). Perencanaan pada dasarnya membuat skenario pembelajaran khususnya memasukkan tugas-tugas pemecahan soal yang memerlukan tingkat pikir tinggi, aplikasi (C-3) ke atas, dan menerapkan Problem Based Instruction dengan mengkaitkan materi ajar dengan kejadian/persoalan riel di lapangan seperti pengamatan reaksi ekso atau endo, reaksi yang cepat dan yang lambat, mempelajari faktor yang mempengaruhi laju reaksi, mempelajari reaksi kesetimbangan, dan penerapan teori kesetimbangan dalam kehidupan nyata (masyarakat dan industri).

Siklus satu membahas kompetensi dasar termokimia yang membahas pengertian enthalpy reaksi, pembentukan, peruraian, enthalpy pembakaran dan Hukum Hess. Pada siklus satu ini tidak banyak kegiatan di laboratorium meskipun siswa menguji beberapa reaksi yang menghasilkan panas maupun yang membutuhkan panas. Namun demikian siswa diberi tugas untuk mengamati beberapa reaksi seperti reaksi pembakaran, terjadinya ledakan pada petasan, serta penguapan dan kelarutan beberapa bahan yang memerlukan atau menghasilkan panas.

Siklus dua membahas laju reaksi: konsep dasar laju reaksi, faktor yang mempengaruhi laju reaksi dan orde reaksi serta teori tumbukan. KBM yang dilaksanakan adalah dengan ceramah, tanya jawab, praktikum, dan tugas khususnya memecahkan soal-soal setingkat Ujian Nasional dan atau olimpiade tingkat Kabupaten/kota. Dalam KBM siswa juga diminta mencatat reaksi-reaksi kimia di lingkungannya seperti terbakarnya bahan bakar, meledaknya petasan, perkaratan besi, pembuatan tape, dan tugas penelusuran melalui sumber pustaka termasuk di dalamnya penelusuran lewat internet.
Siklus tiga sebagai siklus cadangan, kalau dua siklus terdahulu belum berhasil, membahas kesetimbangan reaksi: konsep kesetimbangan, definisi, faktor yang mempengaruhi pergeseran kesetimbangan dan aplikasi kesetimbangan dalam industri. Dalam membahas topik ini siswa juga diberi tugas mengamati kesetimbangan dalam fisika maupun dalam kimia, menelusur pustaka dan internet. Tindakan KBM bervariasi seperti ceramah, tugas, praktek, tanya jawab dan pemecahan soal-soal HOT. Pada akhir sub topik siswa diberi quick test dan atau tugas memecahkan soal-soal secara berkelompok.

Instrumen penelitian meliputi (1) tes hasil belajar kognitif, (2) lembar pengamatan aktivitas siswa di kelas, (3) lembar pengamatan praktek, (4) lembar pengamatan karakter siswa, dan (5) angket respons siswa terhadap pembelajaran HOT-PBI. Validasi instrumen dilakukan oleh tim berdasarkan isi instrumen, dibandingkan dengan isi tuntutan kurikulum, dan kesesuaian instrumen dengan teori (construc validity berdasarkan pertimbangan ahli). Data berupa data kuantitatif hasil tes kognitif, data pengamatan aktivitas siswa, data karakter siswa dan data respons siswa. Pengukuran aktivitas, afeksi terkait karakter dan respons siswa menggunakan rating scale skala 1 sampai dengan 5 yang menggambarkan sangat kurang sampai sangat baik. Dalam hal ini guru sangat berperan karena guru yang paling hafal pada siswa-siswa sehingga gambaran pengamatan karakter lebih akurat.

Analisis data dilakukan secara deskriptif kualitatif menggunakan pendekatan triangulasi data interaktif (Huberman), yakni: (1) pemilahan dan pemilihan data relevan; (2) pemaparan data disesuaikan dengan target; dan (3) verifikasi-pengambilan simpulan. Meskipun data target dinyatakan dengan bilangan tetapi tetap dilakukan analisis secara deskriptif yang diperlukan untuk pengambilan simpulan secara kualitatif, khususnya dalam pengkategorian simpulan. 


\section{HASIL DAN PEMBAHASAN}

Hasil

Penelitian ini menerapkan pembelajaran dengan memecahkan masalah yang memerlukan pemikiran tingkat tinggi (minimum C-3) dalam bentuk pemecahan soal-soal setingkat Ujian Nasional dan Olimpiade tingkat kota/kabupaten. Pembelajaran ini sebelumnya belum pernah dilaksanakan di SMA N 1 Ungaran, sebagai akibatnya siswa terkejut dengan model latihan soal yang "langsung" sulit, siswa merasa tertekan atau takut karena tugas tidak dapat dikerjakan dengan baik. Sebagai akibatnya pada siklus satu siswa kurang berhasil. Namun dengan pendekatan yang baik, maka siswa secara tekun dan bertanggungjawab mau berlatih dan terbuka (jujur) pada guru.

\section{Hasil Siklus 1}

Hasil tes siklus 1 (termokimia) kurang memuaskan karena rerata kelas hanya 64,91 dengan simpangan baku 13,10, masih di bawah target 70. Demikian pula siswa yang tuntas dengan soal HOT hanya 40,63\% masih jauh di bawah target $85 \%$ siswa tuntas. Dari hasil refleksi dicari cara penyelsaian soal HOT dengan bentuk kerja kelompok. Dengan penyediaan waktu lebih banyak untuk berlatih serta memperbanyak latihan dan tugas, siswa dilatih untuk pengembangan karakter berani menghadapi tantangan berat, kerja keras, kerja tekun, berbagi dengan sesama anggota kelompok dan melatih tanggungjawab terhadap tugas, tim peneliti juga perlu mendampingi jika siswa mengalami kesulitan. Dalam hal ini tim peneliti tidak melepas siswa untuk mengerjakan penyelesain tugas.

Penilaian terhadap aktivitas belajar juga kurang memuaskan karena pada siklus pertama tidak ada aktivitas praktikum sehingga aktivitas lebih banyak di kelas. Secara rerata nilai aktivitas siswa di kelas adalah 78 lebih tinggi dari target 70,tetapi aktivitas di laboratorium kurang; yaitu adalah 60 lebih rendah dari target 70. Dari aspek karakter ilmuwan, skornya juga belum maksimal. Karakter minimal siswa RSBI memang sudah terbentuk, tetapi belum maksimal. Sikap tekun, tanggungjawab, kerja keras, berani menghadapi tantangan masih perlu ditingkatkan.

Demikian pula bentuk kerjasama untuk meraih sukses bersama masih kurang. Refleksi siklus pertama untuk aspek aktivitas dan pengembangan karakter dihasilkanimpulan bahwa siswa belum dapat dilepas untuk mengerjakan tugas secara mandiri. Guru dan tim peneliti perlu mendampingi kegiatan siswa di kelas dan di laboratorium. Siklus kedua dirancang skenario pembelajaran yang lebih banyak aktivitas belajar siswa termasuk menyelesaikan soal-soal HOT. Dengan pendampingan guru dan tim peneliti diharapkan siswa tidak tertekan, siswa berani bertanya, jujur atau berterus terang jika mengalami kesulitan. Dengan dibentuk kelompok, mereka bisa saling membantu memecahan tugas, dan mereka merasa kesalahan kelompok lebih meringankan daripada ditanggung secara individual.

\section{Hasil Siklus 2}

Siklus kedua skenario pembelajarannya diperbaiki, ada tugas praktek laju reaksi dan ada pendampingan pada siswa. Siswa sudah mau menerima kenyataan bahwa soal-soal itu meskipun sulit harus diselesaikan bukan dihindari. Hasil tes kognitif pada siklus kedua adalah 73,84 , jumlah siswa yang tuntas $96,87 \%$. Hasil tes kognitif itu lebih tinggi dari target rata-rata 70, demimkian jumlah yang tuntas juga lebih tinggi dari $85 \%$. Dengan kerjasama yang baik antar siswa, dan pendampingan guru kelas, aktivitas belajar juga menjadi lebih baik, ratarata 83,81 lebih tinggi dari target 70 . Karakter yang dikembangkan juga lebih baik. Pada siklus kedua tanggungjawab siswa lebih baik, siswa berani menghadapi tantangan meskipun perlu pendampingan guru. Dalam kerjasama antar siswa juga nampak kemajuan. Tugas praktikum dikerjakan dengan baik. Berdasarkan hasil siklus kedua, target PTK sudah tercapai, namun untuk menguji kestabilan hasil penelitian, pembelajaran dengan HOT itu tetap diteruskan sampai Ualngan Umum semester 1. Hasil ulangan umum kelas XI IPA-3 adalah 74,21 masih lebih tinggi dari target 70 . 
Sementara itu, jumlah yang tuntas pada Ulangan umum adalah 74,19\% lebih kecil dari syarat $85 \%$. Hal ini dapat dimaklumi karena bahan untuk ulangan umum adalah seluruh bahan semester gasal. Jika hasil kognitif itu dibandingkan dengan siklus kedua, nampak hasilnya relatif stabil, siklus kedua rata-rata 73,84 sementara ulangan umum rata-rata 74,21. Dari aspek karakter skor rata-rata pada siklus kedua adalah 88,08 yang lebih tinggi dari target 70 . Jika dinilai dengan rentang skor $1-5$, rerata skor karakter adalah 4,4 yang termasuk baik. Dari jawaban angket respon siswa terhadap pembelajaran HOT diperoleh rerata skor jawaban 4,11 yang termasuk baik yang berarti siswa memberi respons positif terhadap pembelajaran HOTPBI.

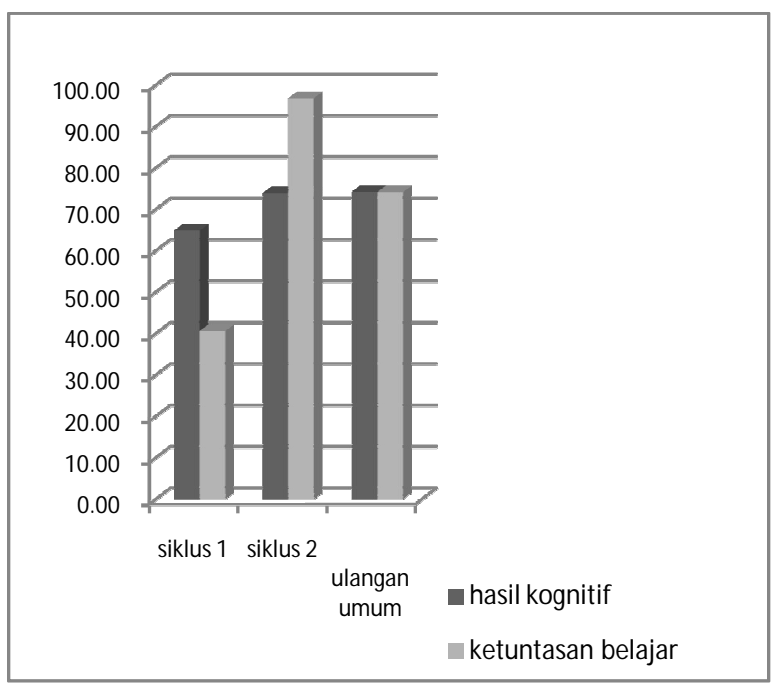

Gambar 1. Rerata Skor Hasil belajar dan Persentase Siswa yang Tuntas

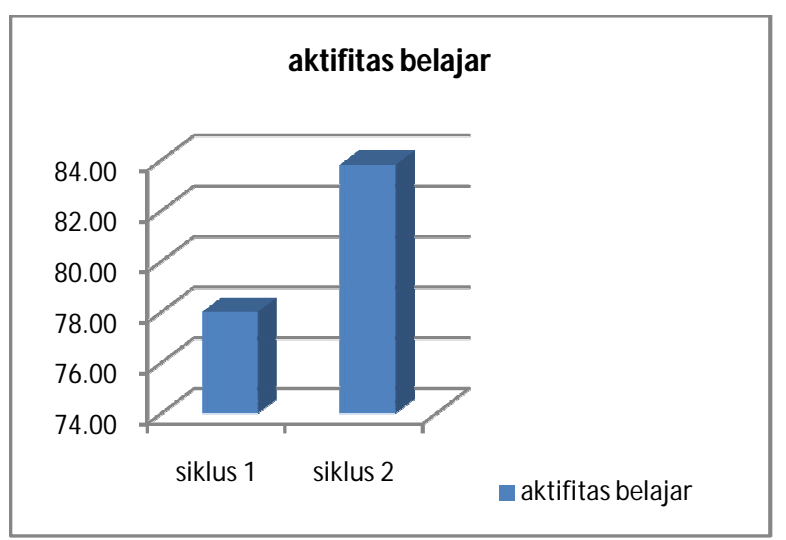

Gambar 2. Rerata Skor Aktivitas Belajar di Kelas dan di Laboratorium

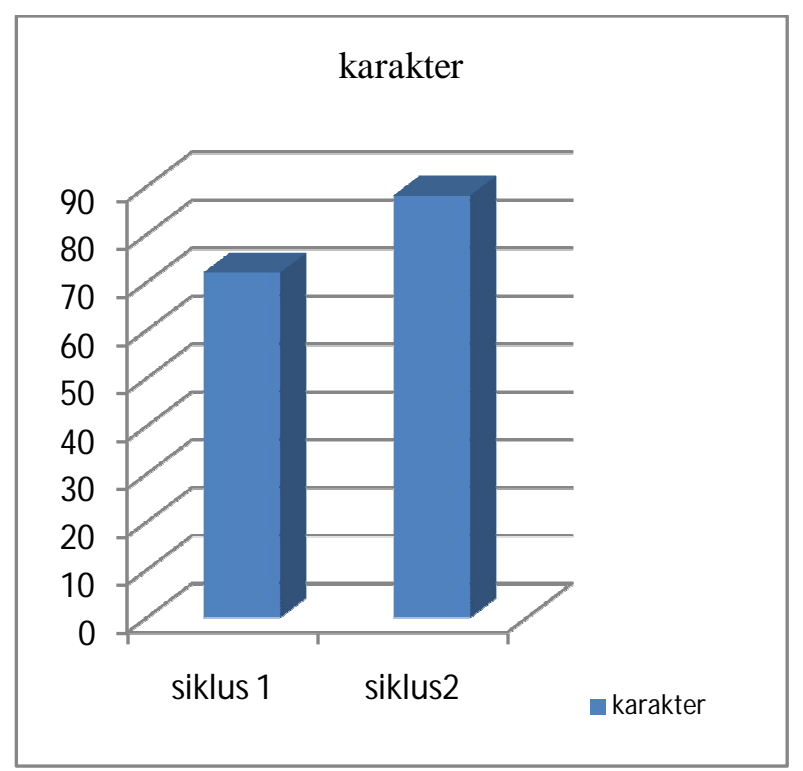

Gambar 3. Rerata Skor Karakter Siswa

\section{Pembahasan}

Pada bagian pendahuluan sudah dituliskan bahwa ujian nasional dianggap sebagai momok yang menakutkan bagi sebagian besar siswa. Para siswa takut tidak lulus karena soalsoal ujian nasional pada umumnya sulit. Sikap takut itui kurang sesuai dengan karakter siswa sekolah unggulan. Pembelajaran dengan pendekatan HOT-PBI dengan pemecahan soal sulit diperlukan untuk menyiapkan siswa berani menghadapi masalah, berani menghadapi tantangan Ujian Nasional maupun tes olimpiade , dan sekaligus meningkatkan karakter siswa. Haryanto (2011) menyatakan bahwa soal-soal yang memerlukan kemampuan berpikir tingkat tinggi seyogyanya harus dilaksanakan di Sekolah Bertaraf Internasional. RSBI atau SBI sudah seharusnya menggunakan soal-soal dengan jenjang kesulitan C-3 (palikasi) ke atas.

Selanjutnya juga dinyatakan bahwa siswa-siswa RSBI atau SBI sudah selayaknya diajak untuk mampu memecahkan masalah. Wena (2011) menyatakan bahwa strategi pemecahan masalah dengan pola pikir tingkat tinggi siswa telah membuktikan bahwa ia mampu. Jika siswa mampu memecahkan masalah atau soal yang sulit, hal itu akan membuat siswa bangga, senang dan terbetuk longterm memory. Dalam kerjasama memecahkan soal dengan pemikiran tingkat tinggi itu terjadi aktivitas pembelajaran yang tinggi, terjadi interaksi antar siswa, 
memberi dan menerima masukan, mengelaborasi, berhipotesis, mencari solusi atau sintesis pengujian hipotesis, menggeneralisasi temuan dan karakter lainnya sehingga terjadi pembelajaran sosio-kognitif yang baik.

Pada penerapan strategi pembelajaran HOT-PBI pada awalnya siswa mengalami kesulitan penyesuaian diri khususnya untuk sekolah-sekolah yang belum pernah menerapkan strategi tersebut. Hal itu nampak dari hasil tes siklus satu di SMA N 1 Ungaran dengan rerata hasil belajar siklus 1 adalah 64,91. Jumlah siswa yang tuntas sebesar $40,63 \%$ menunjukkan hawa target belum tercapai, demikian pula jumlah yang tuntas tidak mencapai 85 . Dengan demikian, pendekatan HOT-PBI pada awalnya tidak mencapai target.

Hasil yang di bawah target pada siklus 1 merupakan hal yang wajar karena siswa belum terbiasa menghadapi soal sulit. Namun sekolahsekolah setingkat RSBI atau SBI pada umumnya memiliki input siswa yang baik, khususnya dalam potensi akademik sehingga dapat segera menyesuaikan diri dan tidak sulit untuk berlatih memecahkan soal dengan kesulitan tinggi. Meskipun demikian jika siswa tidak dilatih maka mereka tetap mengalami kesulitan khususnya pada tingkat awal. Untuk itu penerapan HOTPBI tidak bisa hanya dilakukan sesekali tetapi harus rutin.

Pada siklus kedua siswa dapat mencapai target rerata minimal 70 , yaitu 74 dengan jumlah siswa yang tuntas $96,87 \%$. Hal itu tetap dipertahankan pada ulangan umum dengan hasil belajar sebesar 74,21. Berdasarkan temuan ini tim peneliti menemukan fakta yang sesuai dengan teori pembelajaran dengan HOT. HOT menyebabkan interaksi siswa-siswa dan siswaguru menjadi lebih baik, aktivitas siswa yang lebih baik mengakibatkan hasil belajarnya juga baik. Di samping itu HOT-PBI menyebabkan siswa perlu kerjasama untuk bertukar pendapat dalam hal memecahkan soal, bertoleransi dalam hal kerjasama, ada rasa tanggungjawab yang besar serta tekun berlatih. Hal itu cocok dengan teori pengembangan karakter siswa, di mana karakter dapat dilatihkan, dan dapat diajarkan pada siswa (Mutohir, 2011). Siswa berani menghadapi tantangan meskipun awalnya mengeluh tetapi lama-lama menjadi kebiasaan, bahkan menurut beberapa siswa, jika mereka mampu memecahkan soal sulit mereka akan senang dan bangga, ingatan itu terbawa dalam waktu yang lama (long term memory).

Aktivitas belajar siswa juga melebih target minimal 70, bahkan pada siklus kedua tercapai skor 83,81 menunjukkan bahwa HOT dapat diajarkan dapat dilatihkan. Dengan tantangan soal sulit, akan terbentuk usaha belajar siswa menjadi lebih giat belajar dan dalam hal ini juga terbentuk karakter-karakter positif yang mendukung seperti rasa tanggung jawab, tekun, toleransi, disiplin, jujur dan objektif, mau bekerjasama, demokratis dalam hal memberi dan menerima ide teman lain. Pada umumnya RSBI memiliki input siswa yang baik bukan hanya dalam hal potensi akademik tetapi juga dalam hal disiplin, ketekunan, sosial-ekonomi, dan tanggung jawab. Modal dasar itu perlu terus dikembangkan asalkan guru kreatif menerapkan strategi pembelajaran yang inovatif. Dalam hal pelaksanaan tugas, siswa-siswa disiplin, bertanggung jawab dan tekun meskipun dari segi hasil tidak $100 \%$ benar. Dari segi kebutuhan finansial atau biaya pada umumnya siswa RSBI tidak mengeluh terlebih jika biaya ditanggung bersama dalam kelompok, demikian juga waktu dan tenaga melaksanakan tugas pada umunya bukan hambatan bagi siswa-siswa RSBI.

Modal karakter yang baik relatif mudah dikembangkan pada sekolah Bertaraf Internasional atau RSBI karena sekolah-sekolah unggulan tersebut menerapkan peraturan yang ketat supaya siswanya bukan hanya unggul dalam hal akademik tetapi juga perilaku atau budaya seperti yang tertulis pada Visi beberapa RSBI. HOT-PBI merupakan salah satu pendekatan pembelajaran Kimia yang cocok diterapkan pada RSBI atau SBI yang memiliki siswa dengan kemampuan akademik baik dan karakter yang baik pula. Efek dari pembelajaran ini dirasakan bukan hanya oleh siswa tetapi juga guru yang merasa mendapat tantangan untuk mampu memecahkan soal-soal sulit sehingga lebih dipercaya oleh murid. Dengan demikian pendekatan HOT-PBI jika dilaksanakan secara 
terus menerus akan mampu meningkatkan kualitas guru maupun murid.

\section{PENUTUP}

Dari penelitian yang telah dilakukan dapat diambil simpulan bahwa penerapan Higher Order Thinking berdasarkan ProblemBased Instruction dapat meningkatkan aktivitas siswa, dan karakter siswa yang akhirnya juga meningkatkan hasil belajar siswa. Target hasil belajar dengan KKM 70, aktivitas belajar siwa 70 dan karakter siswa minimal 70 dapat dicapai pada siklus kedua dan dipertahankan pada masa selanjutnya. Penerapan HOT-PBI mampu meningkatkan interaksi siswa-siswa, dan guru siswa. Siswa lebih berani untuk bertanya pada guru, mengusulkan ide dan terbentuknya keberanian menghadapi soal sulit dapat dijadikan modal menghadapi soal ujian nasional dan atau tes olimpiade.

Berdasarkan temuan ini disarankan supaya di Rintisan Sekolah Bertaraf Internasional maupun yang sudah Berataf Internasional melaksanakan pembelajaran dengan menerapkan HOT pada kegiatan pembelajarannya maupun pada pelakanaan evaluasinya. Sudah selayaknya siswa-siswa RSBI maupun SBI dengan input yang unggul berani menjawab soal-soal sulit dengan jenjang C-3 (aplikasi) ke atas.

\section{Rekomendasi Tindak Lanjut}

Telah teruji bahwa dengan penerapan Higher Order Thinking Problem-Based Instruction dalam pembelajaran Kimia dapat meningkatkan hal-hal positip seperti keberanian menghadapi soal sulit, terbentuknya kerjasama antar siswa yang baik, adanya interaksi siswa-siswa maupun siswa-guru yang lebih tinggi, aktivitas belajar yang lebih baik serta karakter siswa yang baik dalam hal disiplin, ketekunan, tanggung jawab, teliti dan sikap terbuka.

Hal itu secara langsung maupun tidak langsung menunjukkan bahwa penerapan pembelajaran HOT-PBI mampu meningkatkan kualitas pembelajaran sekaligus meningkatkan hasil belajar siswa, baik dalam aspek kognitif, psikomotorik maupun afektif, oleh karena itu direkomendasikan supaya: (1) HOT-PBI diterap- kan dalam pembelajaran Kimia SMA sejak kelas X sampai dengan kelas XII; (2) pada setiap pembahasan kompetensi dasar atau pokok bahasan supaya selalu diberikan soal-soal dengan pola pikir tingkat tinggi dengan mengambil atau mengutip soal Ujian Nasional dan atau soal Olimpiade; (3) penerapan HOT-PBI sekaligus digunakan sebagai sarana pengembangan karakter siswa, khususnya karakter yang terkait dengan ilmuwan seperti teliti, hati-hati, tekun, tanggung jawab, jujur dan kerjasama; (4) penelitian tindakan yang berhasil dan memberi manfaat untuk perbaikan kualitas pembelajaran hendaknya diterapkan bukan hanya pada kelas yang diteliti tetapi dapat diperluas ke kelaskelas yang lain bahkan juga pada mata pelajaran yang lain.

\section{UCAPAN TERIMA KASIH}

Pada kesempatan ini, penulis mengucapkan terima kasih kepada Rektor dan Ketua Lembaga Penelitian Universitas Negeri Semarang yang telah memberikan kesempatan kepada tim peneliti untuk melakukan penelitian ini. Selain itu, penulis juga mengucapkan terima kasih kepada Kepala SMAN 1 Ungaran beserta guru dan siswa yang telah membantu terlaksananya penelitian ini.

\section{DAFTAR PUSTAKA}

Haryanto. 2011. Evaluasi Pembelajaran pada Sekolah Bertaraf Internasional. Makalah, disampaikan pada Workshop Pengembangan Instrumen Evaluasi pada Sekolah Bertaraf Internasional, Jurusan Kimia, FMIPA UNNES, tanggal 7 Mei 2011.

Mc Loughlin, C. and Luca, J. 2000. (http://otl.curtin.edu.au/tlf/tlf2000/mcloghlin.html, diakses tanggal 19 April 2011).

Mutohir, T.C. 2011. Membangun karakter Melalui Olahraga, Makalah Seminar Nasional disampaikan dalam rangka Dies Natalis Program Pascasarjana ke 14 Universitas Negeri Semarang, tanggal 28 Mei 2011. 
Newman, FM and Wehlage, GG. 1993 (http://mathdepartment.wiki.farmington. k12.mi.us) diakses tanggal 19 April 2011).

Nurjanah, N. 2006. Pembelajaran Matematika dengan Pendekatan Pemecahan Masalah untuk Meningkatkan Pemahaman Matematis Siswa. Tesis, Program Pascasarjana UPI Bandung.

Pujiadi. 2008. Pengaruh Model Pembelajaran Matematika CPS Berbantiuan CD Interaktif terhadap Kemampuan Pemecahan Masalah pada Siswa Kelas X. Tesis. Program Pasca sarjana Universitas Negeri Semarang.

Ratnasari, S. 2005. Implementasi Model Pembelajaran Matematika Menggunakan Pendekatan Pemecahan Masalah untuk Meningkatkan Kemampuan Penalaran Deduktif Siswa SMP. Tesis, Program Pascasarjana UPI Bandung.

Russefendi, ET. 1991. Penilaian Pendidikan dan Hasil Belajar Khususnya dalam Pembelajaran Matematika untuk Guru dan Calon Guru. Bandung: Tarsito.
Sujak. 2005. Wacana kebijakan Sertifikasi Tenaga Kependidikan, Makalah Disampaikan dalam rangka Dies Natalis Universitas Negeri Semarang ke-40.

Surya-Dharma. 2009. Arah Kebijakan Peningkatan Mutu Pendidik Tenaga Kependidikan, Makalah disampaikan pada Seminar Nasional dalam rangka Dies Natalis ke-44 Universitas Negeri Semarang.

Suyitno, A. 2006. Handout Kuliah Teori Pembelajaran Matematika. Semarang: Jurusan Matematika FMIPA UNNES.

Thomas, A. dan Thorne, G. S.a. (http://www.cdl.org/resource-library/articles/hot.php diakses tanggal 19 April 2011).

Wena, M. 2011. Strategi Pembelajaran Inovatif Kontemporer: Suatu Tinjauan Konseptual Operasional. Jakarta: Bumi Aksara. 